University of Nebraska - Lincoln

DigitalCommons@University of Nebraska - Lincoln

\title{
A Computer Model for Simulating Population Development of the Indianmeal Moth (Lepidoptera: Pyralidae) in Stored Corn
}

James E. Throne

USDA-ARS, Manhattan, KS, james.throne@ars.usda.gov

Richard T. Arbogast

USDA-ARS

Follow this and additional works at: https://digitalcommons.unl.edu/usdaarsfacpub

Throne, James E. and Arbogast, Richard T., "A Computer Model for Simulating Population Development of the Indianmeal Moth (Lepidoptera: Pyralidae) in Stored Corn" (2010). Publications from USDA-ARS / UNL Faculty. 2035.

https://digitalcommons.unl.edu/usdaarsfacpub/2035

This Article is brought to you for free and open access by the U.S. Department of Agriculture: Agricultural Research Service, Lincoln, Nebraska at DigitalCommons@University of Nebraska - Lincoln. It has been accepted for inclusion in Publications from USDA-ARS / UNL Faculty by an authorized administrator of DigitalCommons@University of Nebraska - Lincoln. 


\title{
A Computer Model for Simulating Population Development of the Indianmeal Moth (Lepidoptera: Pyralidae) in Stored Corn
}

\author{
JAMES E. THRONE ${ }^{1}$ AND RICHARD T. ARBOGAST ${ }^{2}$
}

\begin{abstract}
J. Econ. Entomol. 103(4): 1503-1507 (2010); DOI: 10.1603/EC09400
ABSTRACT The Indianmeal moth, Plodia interpunctella (Hübner) (Lepidoptera: Pyralidae), is a common pest of stored corn, Zea mays L. We developed a computer model to simulate population development of the Indianmeal moth in stored corn by using previously published data describing immature developmental times and survivorship, and adult longevity and fecundity. The model accurately simulated population development of Indianmeal moths in corn stored during fall and into winter of three separate storage seasons in South Carolina. This is the period when the Indianmeal moth is a pest in stored corn in South Carolina. The model predicted that populations would increase after winter as grain temperatures rose, but observed populations in the grain bins never increased after winter. Despite this, the model should be useful from a management perspective because the corn is being sold off or used up after winter, and the observed Indianmeal moth populations never reached damaging levels after winter.
\end{abstract}

KEY WORDS Plodia interpunctella, simulation model, stored-product insect

The Indianmeal moth, Plodia interpunctella (Hübner) (Lepidoptera: Pyralidae), is a common pest of stored corn, Zea mays L. (Arbogast and Throne 1997). Adults are short-lived, and a female can lay several hundred eggs (Mohandass et al. 2007). Larvae feed on kernels near the surface of the grain mass, and silken webbing produced by larvae can interfere with grain handling procedures when there are large infestations. Lastinstar larvae move out of the grain to find a place to pupate, often on the surface of the grain.

Computer models can be useful for optimizing control strategies for pests of stored grain or for making real-time pest management decisions (Throne 1995). For example, Arthur et al. (2001) used a model for the maize weevil, Sitophilus zeamais Motschulsky (Coleoptera: Curculionidae), to determine feasibility of aeration (blowing cool air through grain to lower the temperature) for control. Models for simulating population development of insect pests of stored wheat have been incorporated into an expert system that inputs real-time insect sampling data and grain abiotic conditions, uses the models to predict insect population growth, and then uses a rule base to make management recommendations (Flinn et al. 2007).

Mention of trade names or commercial products in this publication is solely for the purpose of providing specific information and does not imply recommendation or endorsement by the U.S. Department of Agriculture.

${ }^{1}$ Corresponding author: USDA-ARS Center for Grain and Animal Health Research, 1515 College Ave., Manhattan KS 66502-2736 (e-mail: james.throne@ars.usda.gov).

${ }^{2}$ USDA-ARS Center for Medical, Agricultural \& Veterinary Entomology, 1600-1700 SW 23rd Dr., Gainesville, FL 32608.
Several types of simulation models have been developed for the Indianmeal moth. Briggs et al. (2000) developed a model for investigating basic ecological phenomena in the Indianmeal moth, but the model was not intended for pest management uses and does not include abiotic inputs such as grain temperature and moisture. Na et al. (2000) developed a phenology model for predicting peaks of moth emergence. Kaliyan et al. (2007) developed a model for predicting mortality of Indianmeal moths at cold temperatures during winter.

The objective of our study was to develop a computer model that could be used to simulate population development of the Indianmeal moth in stored corn from the initiation of storage (usually around September in the southeastern United States) to winter. This is the period when the Indianmeal moth is a pest in stored corn in the southeastern United States. Populations usually are at low levels after winter (Arbogast and Chini 2005), so the Indianmeal moth is not a pest after winter. The eventual plan is that this model, along with models for other pests of stored corn (e.g., Maier et al. 1996), will be incorporated into an expert system, such as that developed for stored wheat, Triticum aestivum L. (Flinn and Hagstrum 1990), to aid in decision making for management of insect pests in stored corn.

\section{Materials and Methods}

Model Development. Methods used for model development were as in Throne (1989). We used data from Arbogast (2007a) for a wild strain of Indianmeal moth from stored corn to develop equations describ- 
Table 1. Parameters $( \pm \mathrm{SE})$ for equations describing effects of temperature on biological processes of Indianmeal moths in stored corn

\begin{tabular}{|c|c|c|c|c|c|}
\hline Process & $a$ & $b$ & $c$ & $n$ & $R^{2}$ \\
\hline Egg-to-adult development (d) & $355.5 \pm 24.1$ & $-21.52 \pm 1.81$ & $0.3557 \pm 0.0328$ & 24 & 0.93 \\
\hline Male longevity $(\mathrm{d})$ & $23.04 \pm 0.759$ & $-0.4860 \pm 0.027$ & & 4 & 0.99 \\
\hline Young female longevity $(\mathrm{d})$ & $18.00 \pm 0.000$ & $-0.4000 \pm 0.000$ & & 4 & 1.0 \\
\hline Lifetime fecundity & $-1,639 \pm 219$ & $144.2 \pm 16.4$ & $-2.766 \pm 0.298$ & 4 & 0.99 \\
\hline
\end{tabular}

All equations are of the form $\mathrm{Y}=a+b \mathrm{X}+c \mathrm{X}^{2}$, where $\mathrm{X}$ is temperature $\left({ }^{\circ} \mathrm{C}\right)$ and $\mathrm{Y}$ is the process being modeled

ing the relationship between temperature and egg-toadult development (Table 1). The data were collected at $20-35^{\circ} \mathrm{C}$, and we extrapolated them to $10^{\circ} \mathrm{C}$. Above $35^{\circ} \mathrm{C}$ and below $10^{\circ} \mathrm{C}$, development rate was set to that at 35 and $10^{\circ} \mathrm{C}$, respectively. Sex did not affect development rate, and we did not include moisture content in the equation because there was no apparent pattern to changes in developmental rate with moisture content (Arbogast 2007a). Survivorship from egg to adult did not differ with temperature or moisture content at $20-30^{\circ} \mathrm{C}$ and averaged $84 \%$ (Arbogast 2007a). Above $30^{\circ} \mathrm{C}$, we used linear regression to predict out to no survivorship at $40^{\circ} \mathrm{C}$ [ survivorship $=3.36-(0.084 \times$ temperature $\left.\left.\left[{ }^{\circ} \mathrm{C}\right]\right)\right]$. Below $20^{\circ} \mathrm{C}$, we used linear regression to predict out to no survivorship at $0^{\circ} \mathrm{C}$ (survivorship $=0.042 \times$ temperature $\left[{ }^{\circ} \mathrm{C}\right]$ )

No published data are available describing longevity of adult males. Brower (1976) showed no difference in longevity of males and females at $27^{\circ} \mathrm{C}$ and $60 \%$ $\mathrm{RH}$. Although not compared statistically, longevity of males and females did not seem to differ at $28^{\circ} \mathrm{C}$ and $65 \% \mathrm{RH}$ in a study by Huang and Subramanyam (2003). So, we used female longevity data from Arbogast $(2007 \mathrm{~b})$ to describe longevity of males. The relationship was linear from 20 to $35^{\circ} \mathrm{C}$ (Table 1), and we extrapolated the equation to 10 and $40^{\circ} \mathrm{C}$. Above $40^{\circ} \mathrm{C}$, we used the same longevity as at $40^{\circ} \mathrm{C}$; below $10^{\circ} \mathrm{C}$, longevity was set to $20 \mathrm{~d}$.

The female stage was split into young and old females, based on data from the longevity study by Arbogast (2007b). Young females were considered to be those up to the age where $75 \%$ of eggs are laid. There are no data to indicate that moisture content has an effect on longevity, so we used a linear equation to predict young female longevity (Table 1). Above $40^{\circ} \mathrm{C}$, longevity was set the same as at $40^{\circ} \mathrm{C}$; below $15^{\circ} \mathrm{C}$, longevity was set to $7 \mathrm{~d}$. Longevity of old adult females was set to $2.7 \mathrm{~d}$.

Fecundity data are from Arbogast (2007b). A quadratic equation was used to describe the data (Table 1), which are extrapolated from 10 to $40^{\circ} \mathrm{C}$. Effects of relative humidity on fecundity are simulated based on Mbata (1985) using linear regression to reduce fecundity when relative humidity is below $75 \%$ ( $\%$ total fecundity $=0.01262 \times$ relative humidity .

Inputs for the model are the starting and ending days of the simulation, with day 1 corresponding to 1 January and day 365 corresponding to 31 December of nonleap years; numbers of eggs, adult males, young adult females, and old adult females; and hourly temperatures and relative humidities for the simulation period. During simulation, development rate of each of the above-mentioned stages was calculated based on temperature and relative humidity. Individuals enter a stage simultaneously at the start of a simulation, but passage to the next stage is distributed over time using a time-varying distributed delay (Manetsch 1976). The shape of the curve describing the number of individuals leaving a stage over time was approximated by a member of the Erlang family of density functions. The particular curve for each stage was designated by the parameter $\mathrm{K}$, which is calculated as $\mathrm{DEL}^{2} / \mathrm{s}^{2}$, where DEL and $\mathrm{s}^{2}$ are the mean time to development at a given temperature and the associated variance. $\mathrm{K}$ was calculated for a stage at each temperature and then an average $\mathrm{K}$ for a stage across all temperatures was used in the model, but $\mathrm{K}$ was not allowed to exceed 12 times the shortest developmental time or else the delay becomes unstable (Abkin and Wolf 1976). Emerging adults were distributed at a 1:1 sex ratio (Arbogast 2007a). Number of eggs laid was divided evenly over the young or old female stages at a constant temperature.

Model Validation. We used data from Arbogast and Chini (2005) to test the validity of the model. They collected wandering-phase larvae in cardboard rolls on the surface of stored corn weekly throughout the storage season during $3 \mathrm{yr}$ on two sites in South Carolina. They also recorded hourly temperatures and weekly moisture contents at nine locations on the surface of the grain in each bin, and we used the mean of those nine hourly temperatures or moisture contents, after conversion to hourly relative humidity (using the equation in Throne 1994), as abiotic inputs for the model. Although our intent was to simulate population development in the fall, we continued simulations throughout the storage season to determine whether temperatures were responsible for limiting population growth in spring. The amount of corn in the bins was constant during the studies. The validation studies were terminated when the farmer wanted to start removing corn from the bins.

We used data only from the Bamberg Co. site because there were too many missing data and some anomalies in the insect data for the Barnwell Co. site. There were occasionally missing temperature or moisture content data for the Bamberg Co. site, and we interpolated between adjacent values to compensate for the missing data. We initiated the model with young adult females. We determined the number of young adult females to initiate simulations by trying different initial numbers and then using the number 


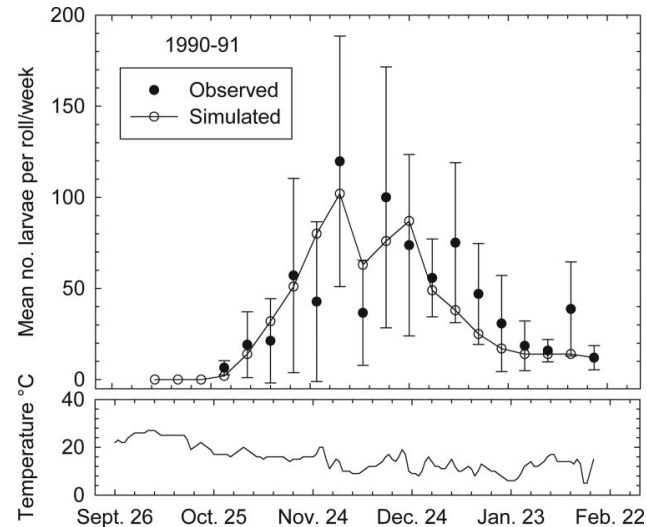

Fig. 1. Mean number of P. interpunctella larvae in cardboard rolls each week in 1990-1991 (error bars indicate 95\% CI), and simulated number of adults emerging each week. Bottom graph shows mean daily grain temperature.

that resulted in populations that best matched the observed data because we did not know the initial size or infestation dates of the infesting populations in the bins. We determined validity of the model by determining whether the simulated numbers of adults were within the $95 \%$ CL on mean number of pupae found in cardboard rolls. This introduces some error, but numbers of pupae in cardboard rolls were determined in the field study, whereas our model predicts egg to adult development because effects of temperature and moisture content on development of individual Indianmeal moth stages has not been determined.

\section{Results}

Simulated numbers of adults emerging between 31 October 1990 and 20 February 1991 were within observed 95\% CL except on the first sampling date when simulated number of adults emerging was lower than the observed lower confidence limit by less than one adult (Fig. 1). After 20 February (data not shown), grain temperature began to rise and the simulated numbers of adults emerging began to increase, but the population in the bin never increased through the rest of study, which ran into summer.

Simulated numbers of adults emerging between 8 September and 15 December 1991 were within observed 95\% CL except on four sampling dates when simulated number of adults emerging was lower than observed lower confidence limit by less than one adult on 29 September; was greater by nine and 17 adults on 13 and 20 October, respectively; and was lower by 14 adults on 8 December (Fig. 2). Simulated populations developed more rapidly than the observed populations during the first few weeks of the study. After 8 December (data not shown), the population in the bins began to drop even though grain temperatures were still suitable for population growth, and the population in the bin generally did not increase through the rest of study which ran into summer.

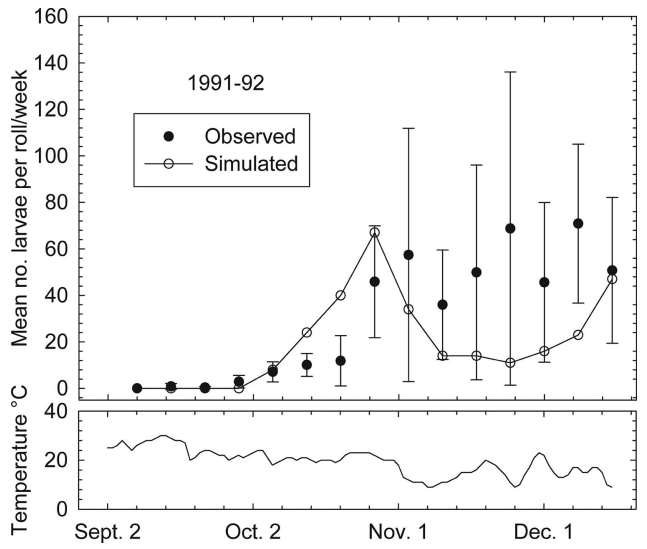

Fig. 2. Mean number of P. interpunctella larvae in cardboard rolls each week in 1991-1992 (error bars indicate 95\% CI), and simulated number of adults emerging each week. Bottom graph shows mean daily grain temperature.

Simulated numbers of adults emerging between 20 September 1992 and 21 February 1993 were within observed 95\% CL except on 6 December when simulated number of adults emerging was higher than the observed higher confidence limit by less than one adult (Fig. 3). After 21 February (data not shown), grain temperature began to rise and the simulated number of adults emerging began to increase, but the population in the bin never increased through the rest of study which ran into summer.

\section{Discussion}

The model fit the data well through the early growth phase of the population in fall and into winter when Indianmeal moths are a problem in corn storages in South Carolina. The fit was best during the first and third storage years, with simulated numbers differing from observed numbers on only one date and by less

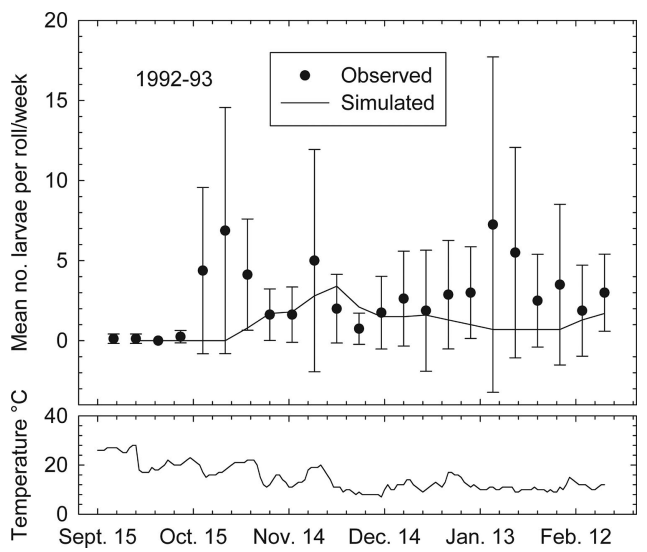

Fig. 3. Mean number of $P$. interpunctella larvae in cardboard rolls each week in 1992-1993 (error bars indicate 95\% CI), and simulated number of adults emerging each week. Bottom graph shows mean daily grain temperature. 
than one individual. During the second storage year, the fit was not as good early in the season with the model overpredicting population growth. We assumed in the simulations that female moths invaded the bins on the first day of storage, and this may not have always been the case. This may account for differences between simulated and observed population levels early in the second storage year.

The observed populations never increased in the bins in the spring despite favorable abiotic grain conditions (Arbogast and Chini 2005). Arbogast and Chini (2005) hypothesized that this may have been due to adversely low temperatures in winter killing the insects, adversely high headspace temperatures in the spring killing insects on the grain surface, and natural enemies. There was no evidence for diapause in the South Carolina populations (Arbogast 2005), although diapause is known in Indianmeal moths (Kikukawa et al. 2009). Simulating populations during spring and early summer is less of a concern from a management perspective because the corn is being sold off or used up during this period, and the observed Indianmeal moth populations never reached damaging levels during this time. However, further studies to clarify what happens to limit growth of the Indianmeal moth populations during this time would be interesting. Indianmeal moth populations in a botanical warehouse followed the same pattern in North Carolina, with large populations in fall, populations declining in winter, and the populations not increasing in size in spring (Arbogast et al. 2002).

Although we had to make some assumptions about affects of extreme temperatures on population growth because of lack of data at these temperatures, that the simulated data fit the observed data well indicates that our assumptions were reasonable or that population development at these temperatures contributes little to population dynamics during fall and into winter. The apparent validity of the model will make it useful for helping to optimize insect pest management in stored corn. As we develop models for other insect pests of stored corn, these models will be used to develop an expert system to aid in decision making for management of insect pests in stored corn.

\section{Acknowledgment}

We thank Paul Flinn for reviewing a previous version of this article.

\section{References Cited}

Abkin, M. H., and C. Wolf. 1976. Distributed delay routines: DEL, DELS, DELF, DELLF, DELVF, DELLVF. Department of Agricultural Economics Computer Library for Agricultural Systems Simulation Document 8, Michigan State University, East Lansing, MI.

Arbogast, R. T. 2005. Seasonal flight activity of stored-product moths (Lepidoptera: Pyralidae, Gelechiidae) in South Carolina, U.S.A. Entomol. News 116: 197-208.

Arbogast, R. T. 2007a. A wild strain of Plodia interpunctella (Hübner) (Lepidoptera: Pyralidae) from farm-stored maize in South Carolina: development under different temperature, moisture, and dietary conditions. J. Stored Prod. Res. 43: 160-166.

Arbogast, R. T. 2007b. A wild strain of Plodia interpunctella (Hübner) (Lepidoptera: Pyralidae) from farm-stored maize in South Carolina: effect of temperature on mating, survival, and fecundity. J. Stored Prod. Res. 43: 503-507.

Arbogast, R. T., and S. R. Chini. 2005. Abundance of Plodia interpunctella (Hübner) and Cadra cautella (Walker) infesting maize stored on South Carolina farms: seasonal and non-seasonal variation. J. Stored Prod. Res. 41: 528 543.

Arbogast, R. T., and J. E. Throne. 1997. Insect infestation of farm-stored maize in South Carolina: towards characterization of a habitat. J. Stored Prod. Res. 33: 187-198.

Arbogast, R. T., P. E. Kendra, and R. C. McDonald. 2002. Infestation of a botanicals warehouse by Plodia interpunctella and Ephestia elutella (Lepidoptera: Pyralidae). Entomol. News 113: 41-49.

Arthur, F. H., J. E. Throne, D. E. Maier, and M. D. Montross. 2001. Impact of aeration on maize weevil (Coleoptera: Curculionidae) populations in corn stored in the northern United States: simulation studies. Am. Entomol. 47: 104-110.

Briggs, C. J., S. M. Sait, M. Begon, D. J. Thompson, and H.C.J. Godfray. 2000. What causes generation cycles in populations of stored-product moths? J. Anim. Ecol. 69: 352366.

Brower, J. H. 1976. Dose fractionation: effects on longevity, mating capacity, and sterility of irradiated males of the Indian meal moth, Plodia interpunctella (Lepidoptera: Phycitidae). Can. Entomol. 108: 823-826.

Flinn, P. W., and D. W. Hagstrum. 1990. Stored Grain Advisor: a knowledge-based system for management of insect pests of stored grain. AI Appl. Nat. Res. Manage. 4: $44-52$.

Flinn, P. W., D. W. Hagstrum, C. R. Reed, and T. W. Phillips. 2007. Stored Grain Advisor Pro: decision support system for insect management in commercial grain elevators. J. Stored Prod. Res. 43: 375-383.

Huang, F., and B. Subramanyam. 2003. Effects of delayed mating on reproductive performance of Plodia interpunctella (Hübner) (Lepidoptera: Pyralidae). J. Stored Prod. Res. 39: 53-63.

Kaliyan, N., M. A. Carrillo, R. V. Morey, W. F. Wilcke, and S. A. Kells. 2007. Mortality of Indianmeal moth (Lepidoptera: Pyralidae) populations under fluctuating low temperatures: model development and validation. Environ. Entomol. 36: 1318-1327.

Kikukawa, S., Y. Arakawa, K. Hayakawa, M. Hayashi, K. Katou, J. Kaneshige, M. Kimura, T. Nakamura, Y. Nakamura, and H. Watanabe. 2009. Effects of skeleton photoperiods on the induction of larval diapause in the Indian meal moth Plodia interpunctella. Physiol. Entomol. 34: 180-184.

Maier, D. E., W. H. Adams, J. E. Throne, and L. J. Mason. 1996. Temperature management of the maize weevil, Sitophilus zeamais Motsch. (Coleoptera: Curculionidae) in three locations in the United States. J. Stored Prod. Res. 32: $255-273$.

Manetsch, T. J. 1976. Time-varying distributed delays and their use in aggregative models of large systems. IEEE Trans. Syst. Man Cybern. 6: 547-553.

Mbata, G. N. 1985. Some physical and biological factors affecting oviposition by Plodia interpunctella (Hübner) (Lepidoptera: Phycitidae). Insect Sci. Appl. 6: 597-604.

Mohandass, S., F. H. Arthur, K. Y. Zhu, and J. E. Throne. 2007. Biology and management of Plodia interpunctella (Lepidoptera: Pyralidae) in stored products. J. Stored Prod. Res. 43: 302-311. 
Na, J. H., M. I. Ryoo, and J. Sone. 2000. A phenology model for seasonal occurrence of Plodia interpunctella (Lepidoptera: Pyralidae) in stored product storage. J. Asia-Pac. Entomol. 3: 77-81.

Throne, J. E. 1989. Effects of noncatastrophic control technologies that alter life history parameters on insect population growth: a simulation study. Environ. Entomol. 18: $1050-1055$.

Throne, J. E. 1994. Life history of immature maize weevils (Coleoptera: Curculionidae) on corn stored at constant temperatures and relative humidities in the laboratory. Environ. Entomol. 23: 1459-1471.

Throne, J. E. 1995. Computer modeling of the population dynamics of stored-product pests, pp. 169-195. In D. S. Jayas, N.D.G. White, and W. E. Muir (eds.), Stored-grain ecosystems. Marcel Dekker, Inc., New York.

Received 25 November 2009; accepted 7 April 2010. 